\title{
Endurance performance of conical picks with hardfacing for improving wear resistance
}

\author{
S-W Choi Korea Institute of Civil Engineering and Building Technology, South Korea \\ C Lee Korea Institute of Civil Engineering and Building Technology, South Korea \\ T Ha Korea Resources Corporation, South Korea \\ T-H Kang Korea Institute of Civil Engineering and Building Technology, South Korea \\ S-H Chang Korea Institute of Civil Engineering and Building Technology, South Korea
}

\begin{abstract}
Conical picks are representative cutting tools for mechanical excavation equipment using a cutting head. The picks include tungsten carbide (TC) tips on their conical bodies to maintain abrasion resistance. Retaining the TC tips is therefore important to maintain the performance of the picks during operation, and hardfacing can simply and effectively achieve this. This study applied martensitic creep-resistant steels as hardfacing on the nose around a conical pick body. Conical picks with and without hardfacing were tested on the cutting head of a transverse type roadheader. The roadheader with the two types of picks excavated a mixed layer of Mantos and conglomerate at a copper mine in Mexico. After excavating for $24 \mathrm{hrs}$, the effect of the hardfacing alloys was investigated by visual inspection, measurement of weight loss, scanning electron microscope (SEM), and X-ray computed tomography (CT). Overall, the picks with hardfacing endured better than those without. However, internal investigation by X-ray CT showed a need to decrease voids between the TC and the nose of the conical body where the weld metal did not penetrate.
\end{abstract}

Keywords: conical pick, hardfacing, mixed ground, excavation, endurance performance

\section{Introduction}

Pick cutters can be radial (drag bits) or conical (point attack picks). The conical picks used here comprised a tungsten carbide (TC) insert, a head to receive the TC insert, and a shaft to be installed into a holder welded to the cutting head of a roadheader. For low rock strength, the penetration of a conical pick cutter is enhanced by using a narrow insert, while for high rock strength a wide insert is best to ensure resistance and durability against a large impact (Sandvik 2010).

The pick cutter penetrates a certain depth into the rock during cutting, and a normal force, a cutting force, and a side force act on its tip. These forces should be within the allowable load of the pick cutter; the resultant force of all the pick cutters acting on the cutting head must also be within its effective torque and power (Balci et al. 2004; Copur et al. 2011).

This study evaluated the performance of three types of pick cutters mounted on the cutting head of a roadheader during the excavation of a tunnel through varying ground conditions and rock strengths at a copper mine in Mexico. Two prototype pick cutters were compared with a conventional pick cutter used in the mine.

\section{$2 \quad$ Equipment and field conditions}

This study used an Antraquip AQM150H roadheader with a transverse type cutting head. The cutting head has 78 pick cutter holders arranged in a spiral array. The left and right cutting drums are symmetrical, with each accepting 39 pick cutter holders (Figure 1). 


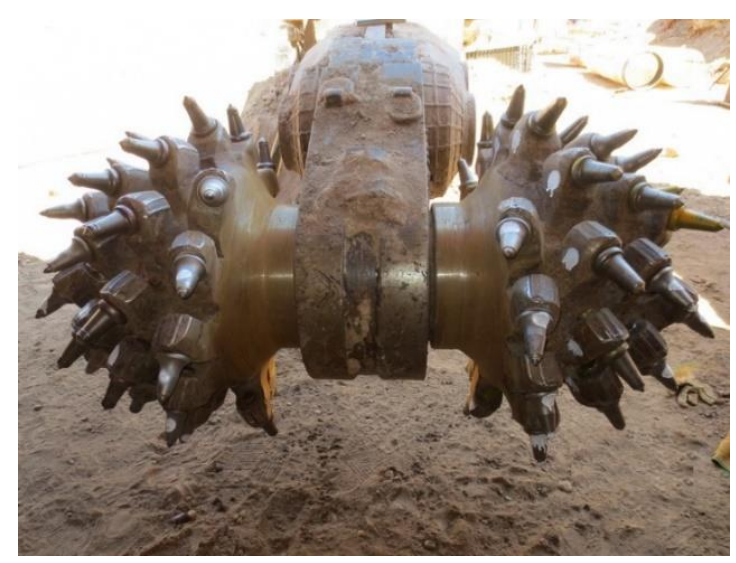

Figure 1 Cutting head of the roadheader $(\mathrm{H}-150)$

The test site is the Boleo mine in Santa Rosalia, Baja California Sur, Mexico which is characterised by mixed ground consisting of Mantos and conglomerate. 'Mantos' is a Spanish term used in mining for mineralised layers or strata (Figure 2). The Mantos layers in the Boleo mine, from which copper, cobalt and zinc are extracted, are very soft with a uniaxial compressive strength of $2 \mathrm{MPa}$, but excavation using roadheaders and continuous miners is difficult due to the mixed conglomerate containing large cobbles (Agapito Associates 2007).



Figure 2 Typical rock conditions of Boleo mine

\section{$3 \quad$ Pick cutters}

\subsection{Pick cutter specifications}

Three types of pick cutter were tested here. A conventional conical pick cutter used in the Boleo mine (Figure $3(a)$ ) was compared with two prototype pick cutters, one without hardfacing (A, Figure $3(b))$ and one with (B, Figure 3(c)).

The tungsten carbide (TC) inserts are the key part of a conical pick cutter because they directly contact and cut the rock surface. The shocks, vibrations and temperature increase occur in the TC insert and the head, while conical pick cutters cut through the rock causing damage or loss of them. In particular, when the rock strength is high and the cutting head is operating at high RPM, the insert of the conical pick cutter must have high impact resistance. Further, the heat generated in the conical pick cutter by the continuous excavation operation causes a decrease in the physical mechanical characteristics of the conical pick cutter (Rostami et al. 1994). In addition, wearing of the head holding the insert greatly reduces the cutter's performance and shortens its life (Thuro 2003). Therefore, the TC insert must have a high level of abrasion resistance and a high toughness to withstand the impact caused by collisions with rock when the cutting head rotates. Table 1 lists the specifications of the TC inserts of the prototype A and B pick cutters. 




(a)



(b)



(c)

Figure 3 Size and shape of conical pick cutters; (a) conventional; (b) prototype A; and, (c) prototype B (Chang et al. 2017)

Table 1 Specifications of TC inserts of prototype A and B pick cutters (Chang et al. 2017)

\begin{tabular}{|c|c|c|c|c|c|}
\hline \multirow{2}{*}{ Pick cutters } & \multirow{2}{*}{$\begin{array}{l}\text { Hardness } \\
\text { (HRA) }\end{array}$} & \multirow{2}{*}{$\begin{array}{l}\text { Grain } \\
\text { size }(\mu \mathrm{m})\end{array}$} & \multicolumn{2}{|c|}{ Components (weight \%) } & \multirow{2}{*}{$\begin{array}{l}\text { Transverse rupture } \\
\text { strength (MPa) }\end{array}$} \\
\hline & & & Co & $\mathbf{w}$ & \\
\hline $\begin{array}{l}\text { Prototype A } \\
\text { (without hardfacing) }\end{array}$ & 86.5 & $3-9$ & 11 & 89 & 2,600 \\
\hline $\begin{array}{l}\text { Prototype B } \\
\text { (with hardfacing) }\end{array}$ & 88.5 & $3-6$ & 8 & 92 & 2,600 \\
\hline
\end{tabular}

\subsection{Installation of conical pick cutters}

The conventional pick cutter and the two prototype (A and B) pick cutters were installed in an AQM 150-H roadheader. To easily identify each type after testing, their shafts were spray painted white, yellow and pink, respectively, prior to installation in the cutting head (Figure 4). The two cutting drums each contained 20 conventional picks; the right drum held a further 19 picks of prototype $A$, while the left drum held 19 picks of prototype B to compare their wear resistance under the same conditions. The machine was set to operate for $24 \mathrm{hrs}$. 


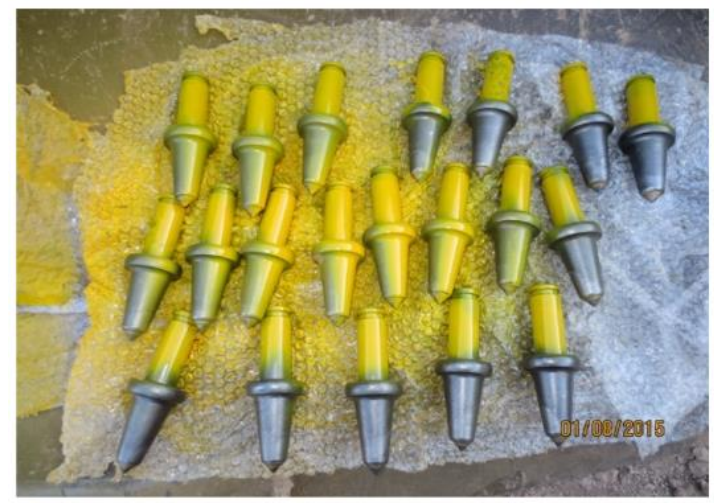

(a)

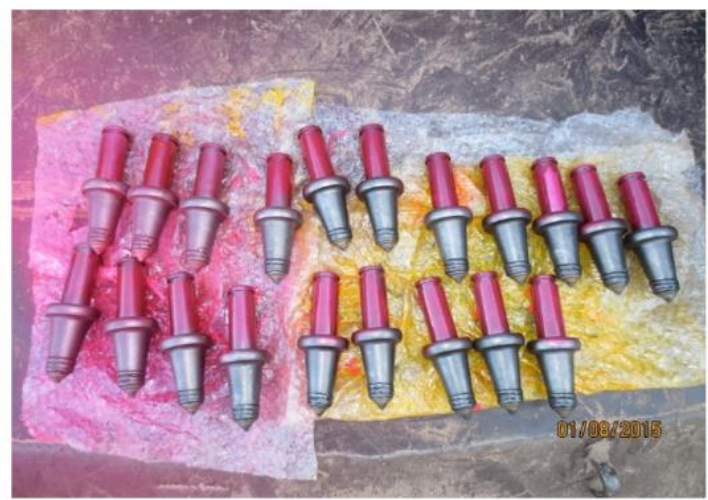

(b)

Figure 4 Prototype pick cutters before installation. (a) Prototype A; and, (b) Prototype B (Chang et al. 2017)

\section{$4 \quad$ Results}

\subsection{Visual inspection and weight loss}

After the $24 \mathrm{hr}$ excavation period, all picks were removed from the cutting head and visually inspected for wear and damage (Figure 5). Loss of TC and wear were more pronounced in the conventional picks than in the two prototypes. The prototype B cutters with hardfacing deposits were less worn than the prototype $A$ cutters without hardfacing.


Figure 5 Visual inspection of conical pick cutters after 24 hrs. (a) conventional and prototype A; and, (b) conventional and prototype B (Chang et al. 2017) 
Table 2 summarises the results of the visual inspection of the picks, and Table 3 lists their weight losses after field testing. Overall, the hardfacing deposits applied to the prototype B cutters reduced excessive wear on the heads and prevented the TC inserts from being detached and lost.

Table 2 Results of visual inspection of conical pick cutters after field testing (Chang et al. 2017)

\begin{tabular}{|c|c|c|c|}
\hline & $\begin{array}{l}\text { Number of cutters } \\
\text { (with TC) }\end{array}$ & $\begin{array}{l}\text { Number of cutters } \\
\text { (without TC) }\end{array}$ & Remarks \\
\hline Conventional & $10(50 \%)$ & $10(50 \%)$ & $\begin{array}{l}\text { Loss of TC insert and severe wear of } \\
\text { head ( } 10 \text { units) }\end{array}$ \\
\hline \multirow{3}{*}{ Prototype A } & \multirow{3}{*}{17 (89.5\%) } & \multirow{3}{*}{$2(10.5 \%)$} & Loss of TC insert (two units) \\
\hline & & & $\begin{array}{l}\text { Wear damage of head wrapping insert } \\
\text { (three units) }\end{array}$ \\
\hline & & & Severe wear of head (one unit) \\
\hline Prototype B & $17(94.4 \%)$ & $1(5.6 \%)$ & Loss of TC insert (one unit) \\
\hline
\end{tabular}

Table 3 Average weight loss of conical pick cutters after field testing (Chang et al. 2017)

\begin{tabular}{|lllll}
\hline & $\begin{array}{l}\text { Average weight } \\
\text { before use } \mathbf{( g )}\end{array}$ & $\begin{array}{l}\text { Average weight } \\
\text { after use } \mathbf{( g )}\end{array}$ & $\begin{array}{l}\text { Average weight } \\
\text { loss (g) }\end{array}$ & $\begin{array}{l}\text { Average weight } \\
\text { loss (\%) }\end{array}$ \\
\hline Conventional & $1,023.15$ & 928.18 & 94.97 & 9.28 \\
Prototype A & $1,031.46$ & 978.38 & 53.08 & 5.15 \\
Prototype B & $1,038.93$ & $1,005.94$ & 32.99 & 3.18 \\
\hline
\end{tabular}

\subsection{SEM and X-ray computed tomography scanning}

SEM and X-ray computed tomography (CT) scanning was conducted to investigate the presence of macro and micro-cracks in the conical picks after field testing. SEM images were captured using an SNE-3000M system with a resolution of $1.0 \mathrm{~nm}(15 \mathrm{kV})$ and magnifications of $\times 100, \times 300$, and $\times 700$. No observable micro-cracks were found in any SEM image, only internal voids and textures intrinsic to each material (Figure 6).

$\mathrm{X}$-ray CT scanning is a non-destructive method of obtaining a large number of consecutive sectional images of the internal micro-structure of a specimen (Kim et al. 2012). The voltage and current for CT scanning were set to $220 \mathrm{kV}$ and $1,000 \mu \mathrm{A}$, respectively. Each CT image had a pixel size of $0.2643 \times 0.2653 \mathrm{~mm}$, with $1,024 \times 1,024$ pixels. They revealed no macro- or micro-cracks in any of the picks. In addition, three-dimensional CT images obtained from X-ray CT scans validated the SEM results by finding no micro-cracks in the picks.

Sintering using silver solder is commonly used to attach and weld TC inserts into the head of a conical pick cutter. Voids between the TC insert and the steel head could emerge owing to vapour generated from heating the silver solder during sintering. CT images showed voids between the TC inserts and the cutter heads in all pick cutters (Figure 7). The average void volumes for the two prototype cutters were much greater than those for the conventional pick cutters. 




(a)

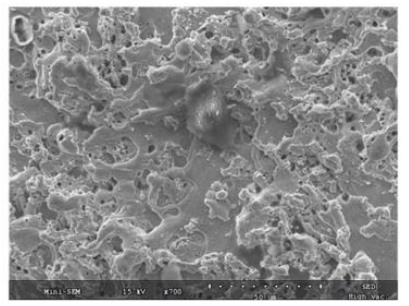

(c)

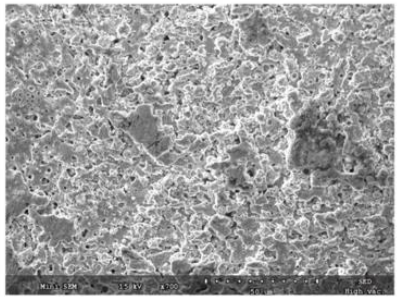

(b)



(d)

Figure 6 SEM images of the prototype A pick cutter (magnification, $\times 100$ ). (a) TC (before test); and, (b) TC (after test); (c) steel (before test); and, (d) steel (after test)

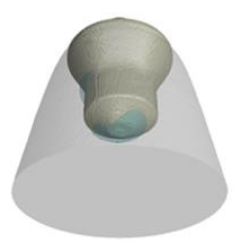

(a)

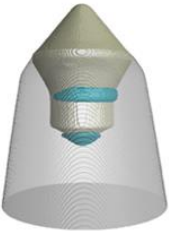

(b)

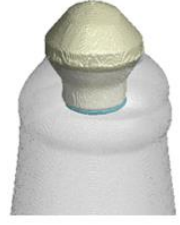

(c)

Figure 7 Voids (blue) between the TC inserts (gold) and the cutter heads. (a) Conventional; (b) Prototype A; and, (c) Prototype B

\section{Conclusion}

This study evaluated the endurance of conical pick cutters with and without hardfacing during digging in the mixed ground of a copper mine. Visual inspection and weight loss measurement of the conical pick cutters after field testing showed that the two prototype picks were harder-wearing than the conventional cutters.

SEM analyses and three-dimensional X-ray CT images showed that none of the pick cutters contained macro or micro-cracks. This indicates that wear and damage do not result from internal cracking, but rather from the mechanical abrasion of the cutter head steel following the wear and loss of the TC inserts.

The voids observed in CT images did not appear to influence the cutting performance of the pick cutters tested here. However, particular attention should be paid to minimising the occurrence of voids between a TC insert and the pick cutter to ensure its strong adhesion and high cutting performance, especially when excavating hard rocks.

In conclusion, applying hardfacing deposits may be an effective way of preventing the loss of TC inserts and of reducing the excessive wear of cutter head steel.

\section{Acknowledgement}

This research was supported by a grant from the Strategic Research Project (Development of Underground Excavation and Stabilization Technologies for the Expansion of Underground Space in Use) funded by the Korea Institute of Civil Engineering and Building Technology. 


\section{References}

Agapito Associates 2007, Geotechnical Evaluation for the Definitive Feasibility Study Underground Mine Design, June 2007, Agapito Associates, Lakewood.

Balci, C, Demircin, MA, Copur, H \& Tuncdemir, H 2004, 'Estimation of optimum specific energy based on rock properties for assessment of roadheader performance', The Journal of The South African Institute of Mining and Metallurgy, vol. 104, no. 11, pp. 633-642.

Chang, S-H, Lee, C, Kang, T-H, Ha, T \& Choi, S-W 2017, 'Effect of hardfacing on wear reduction of pick cutters under mixed rock conditions', Geomechanics and Engineering, vol. 13, no. 1, pp. 141-159.

Copur, H, Balci, C, Tumac, D \& Bilgin, N 2011, 'Field and laboratory studies on natural stones leading to empirical performance prediction of chain saw machines', International Journal of Rock Mechanics \& Mining Sciences, vol. 48, pp. $269-282$.

Kim, KY, Yun, TS, Choo, J, Kang, DH \& Shin, HS 2012, 'Determination of air-void parameters of hardened cement-based materials using X-ray computed tomography', Construction and Building Materials, vol. 37, pp. 93-101.

Rostami, J, Ozdemir, L \& Neil, DM 1994, 'Roadheaders performance optimization for mining and civil construction', Proceedings of 13th Annual Technical Conference, Institute of Shaft Drilling Technology, viewed 7 June 2017, http://emi.mines.edu/UserFiles /File/earthMechanics/roadheader/roadheader3.pdf.

Sandvik, 2010, Mineral Ground Tools - Mining, Product Catalog, Sandvik, viewed 7 June 2017, available online at http://www.miningandconstruction.sandvik.com

Thuro 2003, 'Predicting roadheader advance rates: geological challenges and geotechnical answers', Proceedings of the 50th Year Symposium of The Faculty of Mines, Istanbul Technical University: The Underground Resources of Turkey Today and Future, June 2003 invited lecture, Istanbul Technical University, Istanbul, pp. 1241-1247. 
